\title{
Participation of religious women in the creation of the nursing service in a university hospital (1909-2005)*
}

\author{
Participação de religiosas na composição do serviço de enfermagem em um hospital \\ universitário (1909-2005)
}

\section{Participación de religiosas en la composición del servicio de enfermería en un hospital universitario (1909-2005)}

\author{
Djailson José Delgado Carlos ${ }^{1}$, Raimunda Medeiros Germano ${ }^{2}$, Maria Itayra Padilha ${ }^{1}$
}

This study aimed to analyze the participation of religious women in the creation of the Nursing service in a university hospital in Rio Grande do Norte, Brazil. This is a qualitative social-historical study, which considered as the period of study the years from 1909 to 2005, representing the beginning and the end of the presence of the sisters daughters of St. Anne in the institution. The research was based on survey in documents, reports, minutes, laws and decrees, ordinances, supplemented by interviews with ten professionals and religious women, who worked at the hospital from the 1950s on. It was concluded that the investigated reality coincides with the Brazilian context in terms of lack of preparation from those who act in Nursing; performance of religious women in the hospital and healthcare duties. The nuns daughters of St. Anne were the pioneers and responsible during decades for the internal administration of the hospital and patients' care.

Descriptors: History of Nursing; Nursing; Human Resources; Religion.

Objetivou-se analisar a participação de religiosas na composição do serviço de Enfermagem em um Hospital Universitário no Rio Grande do Norte, Brasil. Estudo qualitativo histórico-social, o qual considerou como período do estudo os anos de 1909 a 2005, corresponde ao início e término da presença das irmãs Filhas de Sant’Ana na instituição. A investigação pautou-se no levantamento de documentos, relatórios, atas, leis e decretos, portarias, complementada por entrevistas com dez profissionais e religiosas, que atuaram no Hospital a partir da década de 1950. Conclui-se que a realidade investigada coincide com o contexto brasileiro em termos de despreparo dos exercentes de enfermagem; atuação das religiosas nos afazeres hospitalares e assistenciais. As Irmãs Filhas Sant'Ana foram as pioneiras e responsáveis, durante décadas, pela administração interna do Hospital e assistência ao paciente.

Descritores: História da Enfermagem; Enfermagem; Recursos Humanos; Religião.

El objetivo fue analizar la participación de religiosas en la composición del servicio de Enfermería en un Hospital Universitario de Rio Grande do Norte, Brasil. Estudio cualitativo histórico-social, que consideró como período del estudio los años de 1909 a 2005, corresponde al inicio y término de la presencia de las hermanas Hijas de Sant’Ana en la institución. La investigación fue basada en el levantamiento de documentos, relatos, actas, leyes, decretos, proyectos, siendo complementada por entrevistas con diez personas, profesionales y religiosas, que actuaron en el Hospital a partir de la década de 1950. La realidad investigada coincide con el contexto brasileño en términos de falta de preparo de los ejecutantes de enfermería; actuación de religiosas en las labores hospitalarios y asistenciales. Las hermanas Hijas Sant' Ana, fueron las pioneras y responsables durante décadas por la administración interna del Hospital y por la asistencia al paciente.

Descriptores: Historia de la Enfermería; Enfermería; Recursos Humanos; Religión.

\footnotetext{
*Taken from the dissertation Past and Present: Nursing University Hospital Onofre Lopes, Universidade Federal do Rio Grande do Norte, 2005.

${ }^{1}$ Universidade Federal de Santa Catarina. Florianópolis, SC, Brazil.

${ }^{2}$ Universidade Federal do Rio Grande do Norte. Natal, RN, Brazil.

Corresponding author: Maria Itayra Padilha

Programa de Pós-Graduação em Enfermagem da Universidade Federal de Santa Catarina, Campus Universitário, s/no - Trindade, CEP: 88040-970 - Florianópolis, SC, Brazil. E-mail: itayra.padilha@ufsc.br
} 


\section{Introduction}

The trajectory of the Hospital Universitário Onofre Lopes [Onofre Lopes University Hospital], located in Natal, capital of Rio Grande do Norte, is marked by successive expansions of its facilities and services, as well as for name changes, namely: Hospital de Caridade Jovino Barreto [Jovino Barreto Charity Hospital] (1909), Hospital Miguel Couto [Miguel Couto Hospital] (1934), Hospital das Clínicas [Clinics Hospital] (1960) and from 1984, on, as a tribute to the first Rector of the Universidade Federal do Rio Grande do Norte [Federal University of Rio Grande do Norte], it was called Hospital Universitário Onofre Lopes [Onofre Lopes University Hospital] ${ }^{(1-2)}$.

Working as a Teaching Hospital since the creation of the Universidade Estadual do Rio Grande do Norte [State University of Rio Grande do Norte] in 1958 , it is today an institution of federal public health, under the Ministry of Health, through the National Health System. It is also a reference to Undergraduate and Graduate Courses of Health Sciences Centers from the Federal University of Rio Grande do Norte. As such, it develops activities of teaching, research, extension and assistance to the population, with outpatient care for more complex services. It is integrated with a Hospital and Health Complex, together with the Maternidade Escola Januário Cicco [Januário Cicco Maternity School], Hospital de Pediatria Professor Heriberto Bezerra [Professor Heriberto Bezerra Pediatrics Hospital], Hospital Universitário Ana Bezerra [Ana Bezerra University Hospital], a community health unit, a center for hematology and hemotherapy services, a dental care service, a pathological anatomy service and a physiotherapy unit.

Returning to its beginnings, when it comes to nursing assistance in the Onofre Lopes University Hospital, it is necessary to clarify its essentially practical nature, due to the absence of a Nursing school in Rio Grande do Norte. At that time, for entering in the Nursing area one was demanded to have manual skills $^{(3)}$, almost always in the case of the Onofre Lopes University Hospital identified by the religious women daughters of St. Anne, among employees, spouses and ex-patients subsequently trained by them ${ }^{(2)}$.

This practical phase was replaced by Modern Nursing, which emerged in the nineteenth century, in London, England, when Florence Nightingale, intending to make the profession honorable and attractive to women, founded the Nightingale School for Nurses annexed to St. Thomas's Hospital which is considered the first professional nursing school worldwide. Its importance was the systematization of teaching and professional practice, making it scientific and rational, which was spread out by its graduates, with the opening of new nursing schools ${ }^{(4)}$.

In Brazil, the institutionalization of modern Nursing occurred in the city of Rio de Janeiro, capital of the Federation at that time, by American nurses assigned to the National Department of Public Health, by the Rockefeller Foundation. They founded and started to work at the Escola de Enfermeiras do Departamento Nacional de Saúde Pública [Nursing School of the National Department of Public Health] today Escola de Enfermagem Anna Nery [Anna Nery Nursing School], from the Universidade Federal do Rio de Janeiro [Federal University of Rio de Janeiro] ${ }^{(5)}$, a pioneer in the country in teaching guided by the system created by Florence Nightingale $^{(3)}$.

Given these brief considerations, the present study aims to analyze the participation of religious women daughters of St. Anne, in the creation of the Nursing Service of the Onofre Lopes University Hospital. Therefore, its relevance is justified by contributing to the memory of the profession and Nursing education, by the redemption of a story not registered yet and the fact that these religious women have remained for decades ahead of the institution that is to Rio Grande do Norte the most traditional reference in the training of health professionals and, in particular, Nursing ones. 


\section{Method}

Qualitative, socio-historical studies gain relevance by the possibility of the construction of scientific knowledge, in a critical and analytical perspective, because they favor the understanding of the past of a social group, as well as contribute to the perception of the professions together with reality. It is therefore a methodologically rigorous activity that allows to return to the roots, activate memories, but without losing the historical background ${ }^{(6)}$. Under this view, conducting historical research is to throw oneself into a challenge that requires organizing ideas, seizing arguments from knowledge, seeking to deepen into the universe to be known ${ }^{(7)}$.

Conducting historical research is to delve into big challenges. The sources of historical research (primary and secondary) are seen as the route by which the researcher comes into contact with the problem, allowing him to examine and analyze a society in its historical context. This relationship between past and present is established through the pursuit of new knowledge, with which one recovers memory, helping to save the past in order to serve the present and the future ${ }^{(8)}$.

Thus, considering the decades when the religious women daughters of St. Anne were present in the Onofre Lopes University Hospital, in this investigation one chose the historical reconstruction through the chronology of events. Thus, the time frame from 1909 to 2005 is justified for being respectively the year of the arrival of the religious women to the Hospital on the occasion of its foundation, and the year when the institution did not record the presence of more religious women among its employees.

The documentary sources of this study consisted of documents, reports, minutes, laws, decrees, ordinances, and the access to them was allowed after a Letter of Assent was received from the files of the State, from the Federal University of Rio Grande do Norte and from the direction of the Onofre Lopes University Hospital, since it contains sources of highest significance about the Hospital.

The data were supplemented by conducting 10 semi-structured interviews between the months of May and June 2005. The interviews lasted for about fifty (50) minutes. In order to participate, it was decided that the professionals should be daughters of St. Anne, teachers from the School for Nursing Assistants of Natal and civil servants from the Federal University of Rio Grande do Norte - who maintained ties with the Onofre Lopes University Hospital from the 1950s on, ie those who experienced part of this story and have vivid memories of it. As a criterion for sample lock one determined the saturation of responses.

The use of interviews favors direct contact with people who witnessed or participated in events of interest to the researcher. Thus, conducting them enables one to verify the worldview and situations, thus resulting in a closer relationship with the object of study ${ }^{(9)}$.

For this research, the interviews followed a prior telephone conversation, through which they were scheduled according to the employees' convenience. On the occasion of the interviews one clarified the objectives of the study, the guaranteed anonymity, the confidentiality of information, the right of refusal and the intention to publish the results of the research. After that, the consent form was signed. Permission was also asked to record the testimony and one stated that they would be transcribed and subsequently transcreated.

The analysis and interpretation of data occurred through careful and detailed reading of the material with which one sought to understand the meanings in an objective, systematic and scientific way. Therefore, the thematic analysis was used to the historical reconstruction of the religious women's involvement in the creation of the Nursing service of the Onofre Lopes University Hospital, for being about specific subjects.

The research was conducted in accordance with the guidelines on research with human 
beings and had the approval of the Research Ethics Committee from the Federal University of Rio Grande do Norte, according to opinion No. 81/2004. To ensure anonymity, speeches were identified with the letter $\mathrm{P}$, referring to professionals and $\mathrm{R}$, for the religious women, both accompanied by the sequential number in which the interviews took place.

\section{Results}

In order to make the Charity Hospital Jovino Barreto work, current Onofre Lopes University Hospital, in 1909 one hired the doctor Januário Cicco, the practical nursing José Lucas Nascimento and for patient care and domestic direction, a group of religious women daughters St. Anne, coming from Recife/PE, Brazil. About them, there is controversy as to the initial number, being either five (Rosa Sampaio, Helena Maria Meneses, Rinalda Mereti and Alinda Gararaglia) $)^{(1)}$ or seven, among whom there was one with a degree in Pharmaceutical Services ${ }^{(2)}$. But consensus is that Sister Cosma Campani, was mother superior $^{(1-2)}$.

Regarding José Lucas do Nascimento, it is known that he was called the first "male nurse" of the hospital, becoming a doctor of poor people, hugely popular under the name of Nurse José. There are records about him as being very dedicated and who headed the Nursing Service in the male wards ${ }^{(10)}$, most likely caused by problems related to purity, chastity, sexuality and honor of the nuns ${ }^{(11)}$.

Regarding the presence of religious women in the hospital, originally contracted in 1909, subordinated to the Mother Superior Cosma Campani, in 1935, the group consisted of nine, with Sister Placida Possi, being the Superior. In 1945, there were thirteen religious women and, in 1952, there were sixteen, on both dates, coordinated by the Mother Superior Albina Vieira ${ }^{(2)}$.

Regarding the secular nursing staff, in 1935, there were the practical nurse José Lucas do Nascimento, Generosa de Souza and Maria de Jesus and two nursing assistants, Joaninha Sales and Francisca Fernandes. In 1945, there were six practical nurses, four men and two women, and two midwives ${ }^{(2)}$.

About these characters, it was worth highlighting that no documents were found referring to their origins, place of birth or even personal data. It can be seen that in a class society, this lack of information can confirm the place that each person occupied in the social hierarchy.

Regarding the participation of the daughters of St. Anne in the hospital affairs, documents from 1952 record the existence of sixteen religious women in several departments, namely: Albina Vieira (Superior), Teodolinda Amazonas (secretary), Natália Maia (pharmacist), Vilma Vila (luxury hall), Delfina Lorraine (1st class hall), Damielina Amaral (admissions sector), Inez Mineli (operating room), Donata (2nd and 3rd class halls), Pierina Albuquerque (1st, 2nd, 3rd, 4th and 5th wards), Alessia Barbosa (6th and 7th wards), Izaura Rego (8th, 9th, 10th, 11th, 12th and 13th wards), Geralda Carvalho (14th, 15th and 16th wards), Miquelina Cassiraghi (entrance and orthodontist and otolaryngology offices), Emerentina Montenegro (kitchen), Conceição Busatta (laundry) and Emerenciana Costa (sewing room) ${ }^{(2)}$.

About the religious women's work, it is known that resources were scarce. It was a very difficult time, often improvised. So we did what was possible. The sisters also worked with the patients (R1). The sisters worked day and night, but despite not having a degree, they had Nursing practice and were trusted by physicians since they worked with a lot of love and dedication (R2). Everything was precarious, sometimes there were no beds for patients to be hospitalized and many times we washed and fixed gloves that had been already used, as well unclogged and rebuilt needles and their tips (R3). It was a time of great difficulty and hard work. We had night shifts but continued working the following day in the morning and sometimes in the afternoon as well, often having to wait for the night to come in order to rest. As religious women we resided at the Hospital, so it was common to be called to work even in moments we were off to rest (R4).

In the hospital the religious women did all kinds of work. They also had administrative functions and each one of them was 
responsible for a hospital or health sector. Some sisters helped to change the patients' clothes, to give food to those who could not feed themselves and also helped with medications (P1).

Regarding the activities undertaken by the daughters of St. Anne, the empirical material has enabled the realization of how effective their participation was in the hospital affairs, sometimes cumulative, being them domestic (entrance, secretarial, admissions sector, kitchen, laundry, linen room, sewing room) or health care (pharmacy, inpatient units, operating room, offices, etc.). And so the hospital remained for decades having the religious women leading the administrative and hospital services.

It is important to highlight the lack of nurses with a degree, religious or secular ones, until July 31, 1953, when Sister Anna Teresa de Jesus Rocha, also known as Sister Amasilles, born in the state of Pará, coming from Recife-PE, who graduated from the Faculdade de Enfermagem Nossa Senhora das Graças [Nossa Senhora das Graças Nursing School], from the University of Pernambuco, became part of the Nursing Board of the Onofre Lopes University Hospital, as well as worked as a professor at the Escola de Auxiliares de Enfermagem de Natal [School of Nursing Assistants of Natal $]^{(2)}$. It is also important to emphasize about her that, along with 11 other nurses, she founded on May 15, 1960, the Associação Brasileira de Enfermagem [Brazilian Nursing Association], Rio Grande do Norte section, being elected as the president from 1960$62^{(12)}$.

Going back to the organization of the Nursing service of the Onofre Lopes University Hospital regarding the care admission the nuns paid attention to the work of the housekeeping staff and to the patients' family members. Those people who stood out, demonstrating a knack for Nursing were invited to join in the Nursing team. I have always shown interest in assistance and in my spare time I helped as a volunteer on patients' care. The sister who worked in the infirmary, one day asked me, would you like to work in the Nursing service? I said yes. So I was trained as an attendant (P1). From the experience as a companion of a patient after surgery and due to the helpful and the delicate way I treated him, I called the sisters' attention, and I ended up being invited to work at the hospital, but I had to do a training (P2). We were required to read, write and do some training. We had theoretical and practical classes (P3).

Regarding this training, it is known that it had a duration of three months, with theoretical and practical classes. It consisted of basic teachings such as: injection techniques, dressings, checking vital signs, bed bath, changing positions, changing clothes and bedding of the patient (P1). When Istarted working at the hospital I had no experience with this Nursing thing. I got in knowing nothing. Sister Geralda Carvalho was my teacher and taught me everything: from dressings to injections. She had the greatest confidence in me and the doctors too. I spent the day taking care of patients on the ward (P2). The nuns explained things to me and I could learn with their explanation. Put a hot water bag like this, they explained how the injection should be made. Learning continued to go on during the job (P3). That was what we could do. We trained those who accepted the invitation because we believed they would perform satisfactorily the Nursing duties as well. After a few classes, we adopted the strategy of placing a novice with an old attendant so that the service could be taught. When it was not possible we put the inexperienced person in a ward with less complex patients. It all happened under our eyes, morning or night (R4).

As the testimonials illustrate, there was the need for professional competence and in an attempt to overcome the difficulties and to operate a nursing school some initiatives were taken. About it, a supervisor from Rio de Janeiro came, from the Ministry of Health, who wrote a report which prohibited the running of the School of Nursing here in Natal. That report, written by Nurse Izaura Barbosa Lima, demonstrated the precariousness of material and technical resources for the operation of a Nursing School. Although this report caused discontent among the leaders of the Society of Hospital Care, the institution that was responsible for managing the Hospital, it brought further studies and observations that ended up bringing, with the Ministry of Education and Culture, authorization to operate a School of Nursing Assistants (P4).

This event, a landmark in the institutionalization of Modern Nursing in Rio Grande do Norte, can be seen as the realization of a long sought dream, because it was in the Internal Regulations of 1927, the year when the administration of the Hospital was transferred to 
the Society of Hospital Assistance, with the intention to operate a School of Nurses and Midwives. About this school, it was created in 1934 and founded in 1950 , however, on both occasions, the lack of human and material resources prevented the development of its activities ${ }^{(13)}$. However, its operation in the premises of the Hospital became possible in 1956 after an agreement between the Society of Hospital Assistance, the Division of Hospital Organization and the National Campaign Against Tuberculosis ${ }^{(2)}$.

However, the hospital's Nursing service remained for a long time under the management of the daughters of St. Anne. The graduates of the School of Auxiliaries did not always belong to the professional body of the institution, starting to work in neighboring states due to financial attractiveness. People found more advantages out there. The wages offered here were low (P5).

This scenario slowly changed after the federalization of the University, which occurred in 1960, moment when the Nursing service of the Hospital started to be done by the nurse from Rio Grande do Norte Nazaré Lira, coming from São Paulo, graduated from USP, especially contracted to organize this transition. With the arrival of the nurses in Nursing leading positions, after the University became federal, things improved greatly. There were changes in the shifts. We started to work six hours a day and the service improved greatly. Before Nazaré, the nuns commanded Nursing and the Hospital because there were no nurses (P2). With the federalization of the University, the administration of the Nursing service, until then, under the responsibility of the religious daughters of St. Anne started to be exercised by the nurses (P6).

Although the religious women left the leadership of the Nursing service, it is noteworthy that they remained in the hospital for decades in other services, such as entrance, admissions, kitchen, laundry and linen, among others. As for the religious hierarchy, sisters Maria Inês Dias, Zélia Ximenes, Anna Teresa de Jesus Rocha, and Esperança, in that order, were the last four daughters of St. Anne to occupy the post of Superiors, but not necessarily the head of the hospital's Nursing service ${ }^{(2)}$.

\section{Discussion}

The foundation of this hospital in 1909, was due to the need to offer adequate assistance to Rio Grande do Norte population ${ }^{(1)}$. Initially installed in an adapted summer house, with only 18 beds and for the care of needy people, it gradually expanded its facilities and services, becoming a teaching hospital and, currently integrating the Hospital and Health Complex of the Federal University of Rio Grande do Norte ${ }^{(2)}$.

The presence of religious women in the hospitals and Santa Casas [Holy Houses] in Brazil began with the arrival of the French Charity Sisters from São Vicente de Paulo, in 1849, to the town of Mariana, Minas Gerais. At that time, these institutions were related to charitable, welfare and economic interests. After this experiment, there were others across the country, causing a new configuration to the routine of health institutions, hitherto mainly composed of slaves, ex-slaves and other uneducated individuals ${ }^{(14)}$.

In the reality of the Onofre Lopes University Hospital the daughters of St. Anne were pioneers and responsible during decades for the internal administration of the hospital and the management of the Nursing service and during that long period, witnessed structural reforms, the modernization of services provided to the population, as well as the institution's successive changes of name.

About the participation of the religious women in the hospital's affairs, it is believed that it was most likely related to the shortage of staff for its various activities and it may have been caused by the lack of financial resources or because the sisters resided within the institution, making them apparently more available, as well as due to the motivation of church values such as: obedience, kindness, selflessness, dedication, compassion, among others.

The reports illustrate other responsibilities of the religious women in the hospital's affairs, because 
besides the aforementioned household and care tasks, they were also responsible for the identification of characteristics and skills among hospital employees and, sometimes, by relations of empathy among patients and companions, and it was their duty to approach them and invite them to receive training for the admission to the Nursing service. This situation deserves careful consideration, since Christian values, to which religious women were subjected, were imposed to the hospital's employees, corresponding to a condition of servitude and neglect of labor rights, for example, the establishment and enforcement of working time, rest, time off, extra hours, vacation and more.

The speeches clarified how the entrance to the Nursing service happened at that time, which usually occurred after the completion of a short training, taught by the religious women and complemented in the service itself, in a practical way, in which the learner continued learning with an experienced employee, under the supervision of the daughters of St. Anne. The situation was precarious by limited human and material resources, but it was arguably the best in terms of hospital care that could be provided in the State of Rio Grande do Norte, at that time.

It is noteworthy that the Modern Nursing in Brazil expanded slowly across the country, given the reality of Rio Grande do Norte, whose teaching, following Nightingale's precepts was possible only 32 years after the foundation of the Escola de Enfermagem Anna Nery [Anna Nery Nursing School], but restricted to the training of nursing assistants, for lack of qualified personnel and infrastructure to run a school of higher level ${ }^{(10)}$.

At this point, the Onofre Lopes University Hospital developed, besides assistance to the population, activities focused on teaching, since their premises started to be used from 1958 on, the year of foundation of the Universidade do Rio Grande do Norte [University of Rio Grande do Norte], by undergraduate students of the Pharmacy, Medicine and Dentistry courses. About it, it must be said that the first initiative of teaching in the hospital's history occurred since 1956, with the running of the School of Nursing Assistants of Natal in their premises ${ }^{(10)}$.

Due to the federalization of the University and therefore the replacement of religious women in the leadership of Nursing services by nurses, it is believed that this institutional decision has probably contributed to a less traumatic transition, considering the long period in which they were ahead of the hospital's administration and Nursing service. This assumption is well illustrated when in the period between 1981-85, the nurse Sister Esperança was chief of the Nursing service of the hospital and due to the permanence of Sister Eurídice de Andrade, Nursing Technician, in the Cardiology Division, until her retirement in the year $2005^{(2)}$.

\section{Final Considerations}

The conduction of this social-historical research has made it possible to record the pre-professional phase of Nursing in the Onofre Lopes University Hospital; allowed to identify the presence of religious women in the hospital and health care affairs; the development of activities with characteristics of priesthood; and the unpreparedness of its professionals. Here well illustrated by the testimonies of the study participants.

In accordance with the reports, it was found that lay people were admitted for this purpose, and sometimes cleaning workers or patients' companions, who showed gestures of solidarity and affection for the sick, were invited to join the nursing staff of the hospital. From that moment on they received training, having as a requirement, not always accomplished, knowing how to read and write.

It should be noted that, even with the creation of the School of Nursing Assistants of Natal, the Onofre Lopes University Hospital, for many decades, stood under the guidance of the daughters of St. Anne. The graduates of this school did not always start to join the staff of the hospital, because many left to work in other 
states of the country, mainly in the Southeast Region, due to the financial attractiveness, or were hired by other existing health services existing in Natal.

It is worth emphasizing that the Nursing service in the hospital has been changing over the years, lying currently diametrically opposite to that situation of the early twentieth century. The current situation presents itself consisting of a group of nurses with accredited professional qualification (specialists, masters and doctors) which has contributed to the growth of education, research and extension, within the profession.

As to the Onofre Lopes University Hospital, one could conclude after discussing its story, a different course of action. Initially with a welfare nature, it is slowly changing its profile, starting to become in a space for teaching par excellence.

Finally, it is noticed how close and intertwined the stories of the hospital and the religious women daughters of St. Anne are, given the 96 years that they walked together and that surely contributed to the transformation of that, which is the most traditional benchmark for education and health care to Rio Grande do Norte's population. Referring to the religious women, it should be reinforced that they were pioneers and those responsible for the internal administration of the Onofre Lopes University Hospital, as well as the management of patient care for decades.

\section{Collaborations}

Carlos DJD contributed to the study design, literature review, data collection and analysis, final draft of the manuscript and final approval of the version to be published. Germano RM and Padilha MI contributed to the literature review, data analysis, drafting of the article and final approval of the version to be published.

\section{References}

1. Cascudo LC. História da cidade do Natal. 4a ed. Natal: EDUFRN; 2010.

2. Carlos DJD, Germano RM, Padilha MI. História e memória do Hospital Universitário Onofre Lopes, Natal (RN): 1909-2000. Rev Eletr. [periódico na Internet] 2013; 4(2):38-57. Disponível em: www. abennacional.org.br/centrodememoria/here/ here_pesquisavolume.htm

3. Germano RM. Educação e ideologia da enfermagem no Brasil. 4⿳a ed. São Caetano do Sul: Yendis; 2007.

4. Lopes LMM, Santos SMP. Florence Nightingale: apontamentos sobre a fundadora da enfermagem moderna. Rev Enf Ref. [Internet] 2010; 3(2). Disponível em: http://www.scielo.oces.mctes.pt/ pdf/ref/v3n2/v3n2a19.pdf

5. Barreira IA, Baptista SS, Sauthier J, Santos TCF, Peres MA, Oliveira AB, et al. Primeira República: a implantação da enfermagem laica e seus desdobramentos (1889-1930). In: Padilha MI, Borenstein MS, Santos I, organizadores. Enfermagem: história de uma profissão. São Caetano do Sul: Difusão; 2011. p. 219-52.

6. Padilha MI, Borenstein MS, Bastini J, Zytkuewisz GV, Lessamann JC. As fontes historiográficas em pauta: a história oral e a pesquisa documental. In: Borenstein MS, Padilha MI. A Enfermagem em Santa Catarina: recortes de uma história (19002011). Florianópolis: Secco; 2011. p. 37-55.

7. Alberti V. Manual de história oral. 3a ed. Rio de Janeiro: FGV; 2010.

8. Le Goff J. História e memória. 5a ed. Campinas: UNICAMP; 2003.

9. Padilha MI, Borenstein MS, Balleteros $\mathrm{H}$. Investigación histórica en enfermería. In: Prado ML, Souza ML, Carraro TE. Investigación cualitativa en enfermería: contexto y bases conceptuales. Washington: Organización Panamericana de Salud; 2008. p.177-93.

10. Carlos DJD, Germano RM. A escola de auxiliares de enfermagem de Natal e o Hospital Universitário Onofre Lopes. Rev Rene. 2009; 10(1):17-80. 
11. Borenstein MS, Padilha MI. Enfermagem em Santa Catarina (1900-2011). In: Borenstein MS, Padilha MI, organizadores. Enfermagem em Santa Catarina: recortes de uma história (1900-2011). Florianópolis: Editora Secco; 2011. p. 59-82.

12. Carvalho AC. Associação Brasileira de Enfermagem, 1926-1976: documentário. Brasília: ABEn Nacional; 2008.
13. Carlos DJDC, Germano RM. Nursing: history and memories of the construction of a profession. Rev Min Enferm. 2011; 15(4):513-21.

14. Padilha MI. A mística do silêncio: a enfermagem na Santa Casa de Misericórdia do Rio de Janeiro no século XIX. Pelotas (RS): UFPel; 1998. 